\title{
Insect based-protein: A new opportunity in animal nutrition
}

\author{
Odunayo A. Toviho ${ }^{1,2}$ - Péter Bársony ${ }^{1}$ \\ ${ }^{1}$ University of Debrecen, Faculty of Agricultural and Food Sciences and Environmental Management, \\ Institute of Animal Science, Biotechnology and Nature Conservation, Debrecen \\ ${ }^{2}$ University of Debrecen, Doctoral School of Animal Science \\ odunayo.toviho@agr.unideb.hu
}

\begin{abstract}
SUMMARY
The consumption of insect protein, as well as its use in animal feeding, has become a trend. This trend is particularly receiving a lot of attention in animal nutrition because the current protein source of the highest quality in animal feeding which is fishmeal is unsustainable, expensive and its demand is higher than supply. Insect protein can be of great potential in combating world hunger as the world population continues to increase. The potential of insect protein is wide-ranging, it could improve the economics offeed production, lead to cleaner production due to its low environmental footprint.

This review focuses on the need, (nutritional and environmental) advantages of insect protein in feed production, as well as previous research findings.

The unanimous conclusion of the reviewed papers is that insect protein has a great potential in feed production in terms of nutritional value, environmental implication, sustainability as well as economic implication.

However, there is a need for the intensification of research on this alternative protein source in Europe, especially in aquaculture due to the approval of 7 insect species in aquafeeds by the European Union. Another reason for the intensification is that there is still much to be done as a result of past research which shows that growth effects vary based on species and inclusion level.
\end{abstract}

Keywords: insect protein, feed, nutritional content

\section{INTRODUCTION}

The world population is projected to reach 8.6 billion of people in 2030 and 9.8 billion in 2050 (Fasolin et al., 2019; Kourrimská and Adámková, 2016), it has been projected that to provide enough food for the increasing population, current food production will need to almost double; but contrary to this, land and water resources are becoming scarce (Van Huis et al., 2013). Hence there is a need to find alternative and sustainable ways of growing food (Machado and Thys, 2019).

Livestock provides a quarter of all the protein consumed in food but also impacts the environment substantially (Herrero et al., 2016; Alexandera et al., 2017). Consumption of animal-based foods has increased throughout the world since the 1960s, due to the sensory qualities of meat, increased production efficiency of the meat industry, and improving global average income and standard of living in growing populations characterized by changing food preferences (Reynolds et al., 2014; Steinfeld et al., 2006; Megido et al., 2016; Elzerman et al., 2011). Meat consumption is predicted increase in upcoming years; relatively, global meat production is also projected to more than double, rising from 229 million tons in 1999/2001 to 465 million tons by 2050 (Steinfeld et al., 2006; Megido et al., 2016). There is however a downside to the expected increase in meat production, as it is responsible for well-known environmental pressure and inefficient conversion of plant protein to meat protein (Megido et al., 2016; Fasolin et al., 2019; Aiking, 2011; Pimentel and Pimentel, 2003). The area of global pasture is more than double that of cropland, with livestock animals additionally consuming around one-third of the crops harvested as feed (FAO, 2006). Despite rises in crop yields and the efficiency of livestock production, global agricultural land area has been expanding, increasing by 464 Mha between 1961 and 2011 (Alexander et al., 2015).

Land-use change in recent decades has accounted for $10-12 \%$ of total anthropogenic carbon dioxide emissions, and a third since 1850 (Alexandera et al., 2017; Houghton et al., 2012).

Food and Agriculture Organization (FAO) has declared that entomophagy has great potential for sustainable nutrition (van Huis et al., 2013). This declaration was based on the high feed conversion efficiency of insects and their ability to utilize a wide variety of feed sources, as well as lower environmental impact compared to conventional livestock farming (Lammers et al., 2019). Insects can be highly nutritious and are a good source of proteins, lipids, minerals, vitamins and energy depending on the species, stage of development (larval, pupae, nymph, adult) and diet (Barroso et al., 2014; Panini et al., 2017). Moreover, their production requires less land and water (Oonincx and de Boer 2012; van Huis et al., 2013 Panini et al., 2017), emits less greenhouse gases and ammonia (Oonincx et al., 2010; Panini et al., 2017), promotes high feed conversion efficiency (Shelomi 2015; Panini et al., 2017) and can be fed different types of organic waste, thus reducing environmental contamination (Panini et al., 2017). However, the favourable properties of some insect species cannot be generalized for all species (Lammers et al., 2019).

Due to the growing threats to global food scarcity, insects are being considered as a new source of human food and animal feed in the western world (Europe and US) (Patel et al., 2019; van Huis et al., 2013). Insects 
are historically consumed in Asia, Africa, SouthAmerica and Central-America where they are farmed or harvested from the wild and are part of the traditional diet (Vargas-Abúndeza et al., 2019; Mancini et al., 2019; van Huis et al., 2013). The reported benefits of the human consumption of insects as an alternative to conventional food animals are numerous and have been reported to include; comparable levels of protein (Testa et al., 2017), and relatively high although variable levels of nutrients and unsaturated fat (Belluco et al., 2013; van Huis et al., 2013), lower environmental impact due to lower emissions of greenhouse gases (Oonincx and de Boer 2012; Testa et al., 2017) and lower land requirements for production (House, 2016; Oonincx and de Boer, 2012).

There has been a noticeable increase in interest in the use of edible insects in the western world, by the scientific community, through the rising number of studies on this subject, and by entrepreneurs, gambling on the production and commercialization of products containing insects for human and animal consumption. This growth can be attributed to a report published by the Food and Agriculture Organization (FAO) in 2013, that promotes the use of insects as a new and sustainable source of protein for humans and animals, based on nutritional and environmental aspects (Machado and Thys, 2019; House, 2018).

The major environmental advantages of insect farming compared to livestock production are: less land and water is required; greenhouse gas emissions are lower; insects have high feed conversion efficiencies; insects can transform low-value organic by-products into high-quality food or feed, and certain insect species can be used as animal feed or aqua feed (Kouřimská and Adámková, 2016; Vargas-Abúndeza et al., 2019; Machado and Thys, 2019). The feed conversion of house cricket (A. domestica) to is twice that of chickens, 4 times higher than in pigs and more than 12 times higher than in cattle (Kouřimská and Adámková, 2016).

\section{Nutritional potential of insect as an alternative protein source}

The nutritional values of edible insects are diverse based on the variability of species, stage of metamorphosis, the origin of the insect and its diet. Similarly, the dynamics nutritional value can also be according to the preparation and processing before consumption (Finke and Oonincx, 2014, de Castro et al., 2018; Kouřimská and Adámková, 2016). Insects have high levels of protein representing the main component of their nutrient composition and they also possess significant amounts of other important nutrients such as lipids, beneficial fatty acids, vitamins and minerals. In comparison to plant and meat proteins, insect proteins have high levels of high-quality proteins in terms of nutritional value, total protein level and essential amino acid profile (de Castro et al., 2018). The Nutrient Value Score of crickets, palm weevil larvae and mealworm was significantly healthier than in the case of beef and chicken. Insects also have a high content of mono- and polyunsaturated fatty acids; they are rich in trace elements such as copper, iron, magnesium, manganese, phosphorus, selenium and zinc, as well as vitamins like riboflavin, pantothenic acid, biotin, and folic acid in some cases (Kouřimská and Adámková, 2016).

The energy value of edible insects depends on their composition; larvae or pupae are usually richer in energy compared to adults. High protein insect species have lower energy content while high-fat content translates to higher energy value (Barroso et al., 2014).

The crude protein content of insects ranges from $40 \mathrm{~g}$ to $75 \mathrm{~g} / 100 \mathrm{~g}$ dry weight (DW), Most of these values could, however, be overestimated due to the use of inadequate nitrogen-to-protein conversion factor and proteins tightly embedded in the chitin matrix (Barroso et al., 2014). The amino acid composition of edible insects was considered, and they contain many nutritionally valuable amino acids including high levels of phenylalanine and tyrosine. Some insects contain large amounts of lysine, tryptophan and threonine, which is deficient in certain cereal proteins. Analysis of almost a hundred edible insect species showed that the content of essential amino acids represents 46-96\% of the total amount of amino acids (Kouřimská and Adámková, 2016). Zielińska et al. in their studies gave the protein content of three insect species as follows: $T$. molitor $52.35 \%$, G. sigillatus $70.0 \%$, and S. gregaria $76.0 \%$ which is also in comparison with values shown by Ramos-Elorduy et al. (1997) for Sphenarium histrio $77 \%$ and, slightly lower, for Schistocerca sp. $61 \%$ (Zielińska, Karaś, and Baraniak, 2018). Barsssos et al., 2014 analyzed 16 species, their protein and fat content; Blásquez et al., 2012; Hall et al, 2017; Zielińska et al., 2015 also analyzed the nutritional content of some insects. There are so many researches that have highlighted the protein content of insect but there is no information available about the biological value. The Table 1 shows the information gathered.

In Nigeria, four popular edible insect species (Imbrasia belina, Rhynchophorus phoenicis, Oryctes rhinoceros, Macrotermes bellicosus) were shown to contain all essential amino acids, with relatively high amounts of lysine, threonine, and methionine, which are the major limiting amino acids in cereal- and legume-based diets (van Huis, 2013).

Fat represents the second largest fraction of the nutrient composition of edible insects and its content is higher in the larval stage of life. Triacylglycerol amount to about $80 \%$ of that, followed by phospholipids, which represents less than $20 \%$ depending on the stage of life. The fat content ranges from $0.66 \mathrm{~g}$ to $77 \mathrm{~g} / 100 \mathrm{~g} \mathrm{DW}$, also depending on species, life stage and environment. Some edible insects contain dietary lipids with essential PUFA) such as linoleic acid, $\alpha$-linolenic acid, longchain PUFA such as EPA and DHA having being detected in several species (Barroso et al., 2014). The fatty acid profile dynamics is based on the species and insects' feed. There are large amounts of $\mathrm{C} 18$ fatty acids including oleic, linoleic and linolenic acids in insect fat and palmitic acid as well (Bukkens, 2005; TzompaSosa et al., 2014). Based on literature lipids from insects possess high amounts of unsaturated fatty acids 
relative to saturated fatty acids (de Castro et al., 2018). Caterpillars are among insects with the highest fat content, the total fat content in caterpillars (Lepidoptera) ranges from $8.6 \mathrm{~g}$ to $15.2 \mathrm{~g}$ per $100 \mathrm{~g}$ of insects. Unlike caterpillars, the fat content of insects in grasshoppers and related Orthoptera species ranges from $3.8 \mathrm{~g}$ to $5.3 \mathrm{~g}$ per $100 \mathrm{~g}$. There is a relatively high content of C18 fatty acids including oleic, linoleic and linolenic acids in the fat of insects. Palmitic acid content is also relatively high. The fatty acid profile is affected by food, which the insects feed upon. Cholesterol is the most abundant sterol in insects (Kouřimská and Adámková, 2016).

Nutritional Value of Some Edible Insect

\begin{tabular}{|c|c|c|c|c|}
\hline Protein sources & $\mathrm{CP} \%$ & Lipid level\% & Ash\% & NFE\% \\
\hline The Black Soldier Fly (Hermetia illucens) larvae & 36 & 18 & 9 & 37 \\
\hline The Black Soldier Fly (Hermetia illucens) adult & 41 & 16 & 20 & 24 \\
\hline Common Housefly (Musca domestica) larvae & 47 & 31 & 7 & 15 \\
\hline Common Housefly (Musca domestica) adult & 40 & 34 & 8 & 18 \\
\hline Yellow Mealworm (Tenebrio molitor) & 58 & 30 & 4 & 8 \\
\hline House cricket (Acheta domesticus), & 73 & 16 & 6 & 5 \\
\hline Field Cricket (Gryllus assimilis) & 65 & 23 & $*$ & $*$ \\
\hline Phyllognathus excavates larvae & 67 & 16 & 8 & 11 \\
\hline Red palm weevil ( Rhynchophorus ferrugineus) adult & 35 & 12 & 7 & 47 \\
\hline Superworms (Zophoba morio) & 54 & 38 & 3 & 6 \\
\hline Bluebottle fly (Calliphora vicina) & 48 & 20 & 8 & 24 \\
\hline Oriental latrine fly (Chrysomya megacephala) larvae & 62 & 27 & 7 & 4 \\
\hline Chrysomya megacephala (Chrysomya megacephala) adult & 47 & 17 & 6 & 31 \\
\hline Dronefly (Eristalis tenax) & 41 & 6 & 14 & 39 \\
\hline Common green bottle fly (Lucilia sericata) larvae & 54 & 28 & 5 & 13 \\
\hline Common green bottle fly (Lucilia sericata) adult & 59 & 27 & 5 & 10 \\
\hline Northern blowfly (Protophormia terraenovae) larve & 46 & 28 & 4 & 22 \\
\hline Northern blowfly (Protophormia terraenovae) adult & 56 & 24 & 9 & 12 \\
\hline Egyptian locust Anacridium aegyptium & 66 & 18 & 4 & 13 \\
\hline Mediterranean Splendid Grasshopper (Heteracris littoralis) & 74 & 9 & 5 & 12 \\
\hline Migratory locust (Locusta migratoria) & 59 & 30 & 4 & 8 \\
\hline Desert locust (Schistocerca gregaria) & 76 & 18 & 10 & $*$ \\
\hline House cricket (Gryllodes sigillatus) & 70 & 13 & 18 & * \\
\hline Corn-field grasshopper Sphenarium histrio & 77 & 12 & 17 & 9 \\
\hline Fishmeal & 73 & 8 & 18 & 1 \\
\hline Soybean meal & 50 & 3 & 8 & 39 \\
\hline
\end{tabular}

(Blásquez, et al., 2012; Barosso et al 2014; Hall, et al, 2017; Zielińska et al., 2015)

$\mathrm{CP}=$ Crude protein

$\mathrm{NFE}=$ Nitrogen free extract

$*=$ Not available

Edible insects contain a significant amount of insoluble chitin which is similar in structure to fibre, it is the most common form present mainly in their exoskeleton. Chitin in commercially farmed insects ranged from $2.7 \mathrm{mg} / \mathrm{kg}$ to $49.8 \mathrm{mg} / \mathrm{kg}$ of fresh weight (from $11.6 \mathrm{mg}$ to $137.2 \mathrm{mg} / \mathrm{kg}$ of dry matter). Chitin is considered as an indigestible fibre, removal of chitin improves the digestibility of insect protein. Chitin is however associated with the defence of the organisms against some parasitic infections and allergic states (Kouřimská and Adámková, 2016).

Edible insects can be interesting in terms of the nutritional content of minerals such as iron, zinc, potassium, sodium, calcium, phosphorus, magnesium, manganese and copper (Kourrimská and Adámková, 2016). Many minerals can be found in insects, such as iron, zinc, potassium, sodium, calcium, phosphorus, magnesium, manganese and copper (de Castro et al., 2018).

Insects contain a variety of water-soluble or lipophilic. Insects are generally rich in riboflavin, pantothenic acid, and biotin and in some cases folic acid vitamins (de Castro et al., 2018; Kouřimská and Adámková, 2016). On the other hand, they are not an efficient source of vitamin A, vitamin $\mathrm{C}$, niacin, and in most cases thiamin. It should be noted that the content of vitamins and minerals in wild edible insects is seasonal and in the case of farm-bred species it can be controlled via feed (Kouřimská and Adámková 2016). 


\section{Insect production}

Some insect species can be successfully grown on organic side streams; they convert low-value organic by-products into high-value proteins. This is particularly of advantage as, $27 \%$ of all our agricultural produce is wasted and $22 \%$ if only the edible part is taken into account, or globally 1.6 and 1.3 billion tons, respectively annually The choice of substrates used depends on legislative frameworks; e.g., in the European Union, the use of organic by-products such as catering waste and manure is prohibited (van Huis and Oonincx, 2017).

Annual agricultural waste was valued at US\$ 750 billion. The by-product that can be used depends on the insect species. Mealworms can be raised on dried organic waste materials from fruit and vegetable origin. Van Broekhoven et al. (2015) and Oonincx et al., 2015 cultured mealworm on mixed dried by-products from beer brewing, bread/cookie production, potato processing, and dried distiller grains with solubles (DDGS), a by-product of the biofuel industry. They found that the mealworms developed well on several of these mixtures and had a fairly constant nutrient composition. Some of these diets were also given to house crickets (Acheta domesticus (L.), but they did not do well on most of these mixtures. The oriental ground cricket, Teleogryllus testaceus (W.), seems to have a broader diet and can be grown on unused resources such as leaves from taro and cashew and cassava tops (Megido et al., 2016).

Miech et al. (2016) found that this species performs well on cassava plant tops, but also on several weeds, in particular Cleome rutidosperma. The best-known species for utilizing waste streams, such as rice straw, coffee pulp, fish offal, DDGS, catering waste and swine, chicken and cattle manure is the black soldier fly.

It utilizes this waste and can simultaneously kill pathogenic bacteria such as Escherichia coli or Salmonella enterica present in, for instance, chicken or cattle manure. And has thus been proposed as a sanitation method for getting rid of human faeces. According to Cicková et al., 2012; Shah et al., 2016 housefly can also be grown on manure. Diptera has also been found suitable for transforming organic waste into high protein feed products by Pastor et al. (2015) (van Huis and Oonincx, 2017).

Hermetia illucens or BSFL for bio-conversion of discarded industrial by-products or side streams, municipal wastes from urban activities have been extensively studied and the economic value it imparts makes it a valuable contender among other solutions recommended. A comprehensive and concise review by Gold et al. (2018) on the decomposition of biowaste types such as human, animal manures, fruits, vegetable wastes, etc. was reviewed recently. Manure management system for laying hens treated with BSFL diminished the manure accumulation by $50 \%$ and yielded $42 \%$ protein, $35 \%$ fat feedstuff is one such example (Ravi et al., 2019). However, they suggested that other fly species such as Muscidae (houseflies), Stratiomyidae (soldier flies), Calliphoridae (blowflies), Sarcophagidae (flesh flies), and Syrphidae (hoverflies) can also be considered.

\section{Insect meal production}

Commercial production of the black soldier fly was developed in Germany to provide an alternative protein source for feed purposes. Applied research is now needed to fill the knowledge gaps by utilizing the prepupae of Hermetia illucens in fish diets. (Kroeckel et al., 2012). Due to the higher lipid concentration defatting, Hermetia illucens should be the primary processing step in the downstream valorization of the insect biomass. For the production of protein, fat/oil and chitin, to be used in animal feed, the raw insect materials must undergo a heat treatment process as described in the legislation on animal-by-products (Regulation (EC) (EFSA scientific committee, 2015). There is a sharp increase in the number of insect companies foraying into the feed market across continental Europe and North America capitalizing on the new regulation on Novel Foods (EU 2015/2283) passed by the European Parliament. The fortification or replacement of conventional feed with Hermetia illucens to augment the protein content has been a time tested idea. The efficacy of Hermetia illucens as a feed additive for poultry and a sustainable aquafeed ingredient has been widely advocated. Li et al. (2016) suggested the benefits of Hermetia illucens as a feed component is not limited to its protein content and quality, its oil as a potential replacement for soybean oil in Jian Carp diets without any negative effect on growth, feed efficiency in fish fillets (Ravi et al., 2019).

Caterpillars of Emperor Moths are among the most widely eaten insects in several African countries (Democratic Republic of the Congo, Republic of the Congo, Cameroon, Ivory Coast, etc) where they are highly appreciated by populations. These insects are generally collected in the wild and sold in local markets. They contribute to the income of rural populations. They are also exported to Europe, particularly France and Belgium. In 2000, these two countries imported respectively from the Democratic Republic of the Congo, 5 and 3 tons of dried Imbrasia sp. caterpillars, with an estimated value of 65,000 US\$ and 41,500 US\$. These insects are sold approximately $15.5 € / \mathrm{kg}$ in Belgium. In the European Union, insects have been recently covered by the new Novel Food Regulation and may continue to be marketed throughout the EU (new Regulation (EU) 2015/2283) (Mba et al., 2019).

The processing affects the nutritional content of insects. Degutting the mopane caterpillar in caused an increase in the crude protein content and digestibility, while cooking lowered them, and hot coal-roasting increased the mineral content, probably due to contamination. Toasting and solar drying can decrease the in vitro protein digestibility and vitamin content of edible winged termites (Macrotermes subhylanus) and the edible grasshopper Ruspolia differens. In smokedried samples of Rh. phoenicis and Oryctes monoceros larvae, cholesterol concentrations were approximately $60 \%$ and $20 \%$ of those of the raw and fried samples, 
respectively. Hence, the optimal processing methods need to be investigated to promote commercialization of insect products.

The characteristics of the protein need to be determined, e.g., solubility, thermal stability, and capacity to gel, form fibre, emulsify, and foam, and the sensory properties need to be established too. For insects used as feed, the process of extracting proteins would be too expensive, but insects still need to be grown, harvested, dried, ground, and packaged (van Huis, 2013).

\section{Potential of insect meal in the feed industry}

Insects are a potential protein source in poultry (Maurer et al., 2016; Bovera et al., 2016; Allegretti et al., 2018; Kierończyk et al., 2018); swine (Jin et al., 2016), fish (Bruni et al., 2018; Dietz and Liebert, 2018; Feng et al., 2019; Henry et al., 2018; Stenberg et al., 2019; Vargas-Abúndeza et al., 2019; Wang et al., 2019), shrimp (Panini et al., 2017) and companion animal nutrition (Bosch et al., 2014). The crude protein (CP) content of insects is species-dependent and varies from $40 \%$ to $60 \%$ (Makkar et al., 2014). It should be emphasized that the CP quality also depends on the production technology and feed composition for larval rearing. However so far, in the European Union, the usage of insect meal in livestock nutrition is banned (Regulation (EC) No. 1069/2009) because these compounds are considered to be processed animal protein (PAP, Regulation (EC) No. 999/2001). Currently, the EU Standing Committee on Plants, Animal, Food and Feed (SCoPaFF) only allows the use of insects as a protein source in the case of fish, mink and pet-food nutrition. Birds were fed soybean-maize diets developed by replacing $50 \mathrm{~g} / \mathrm{kg}$ of the basal diet with various fats i.e., soybean oil (SO) and TM (Exp. 1), or SO, TM, and ZM (Exp. 2). Overall, these results highlight the possibility of completely replacing SO with TM and ZM oils in broiler diets without adverse influences on growth performance and nutrient digestibility. Moreover, the results of the present study suggest that TM oil positively affect meat quality which is a key factor for the modern consumer (Kierończyk et al., 2018).

In particular, Hermetia illucens or the Black Soldier Fly larvae (BSFL) belonging to the Diptera order is being contemplated as a promising substitute to replace the conventional protein sources to an extent. Industrial rearing, processing, and valorization of BSFL presents its own challenges, yet their nature to aggregate the micro, macro-nutrients (Barroso et al., 2017) present in the feeding medium thereby giving proteins, lipids, chitin derivatives, bioactive Insect meal in feed industry peptides, and organic manure makes them an attractive candidate for numerous applications (Ravi et al., 2019).

Potential of insect meal in the aquaculture industry

The development of commercial aquatic feeds has traditionally been dependent on fishmeal (FM) as the main protein source (Henry et al., 2015). Due to the decrease in the availability and the increase in the prices of FM the search for sustainable alternatives have prompted.

Plant feedstuffs are usually deficient in protein contents, essential amino acid balances, presence of anti-nutritional factors and absent of certain FM components (i.e. taurine and hydroxyproline) leading to the potential problems of poor growth performance, intestinal inflammation and decreased palatability. Over the last decade, the value of insect protein as partial or complete replacements for FM has been studied. (Wang et al., 2019) The European Commission has recently approved the use of processed insect protein in aquafeeds (Regulation 2017/893/EC, 2017) (Wang et al., 2019; Bruni et al., 2018). The recent EU commission regulation (2017/893-24/05/2017) authorized the use of 7 insects ( 2 flies, 2 mealworms, 3 cricket species) in aquafeeds, this will further motivate the intensification of their production (Henry et al., 2018).

As a result of their minimal environmental impact, compared to most conventional feed commodities, insects should be explored as candidate ingredient for aquafeeds.

They are cultured through environmental-friendly, cost-effective farming processes since they can be produced on by-products or wastes. They are rich in proteins, with an essential amino acid composition similar to that of FM, and high in lipids too (VargasAbúndeza et al., 2019).

The replacement of expensive and unsustainable fish meal (FM) and fish oil in aquafeeds has already received a lot of attention for finfish production to ensure increased profitable and sustainable. Researches have however focused on commodities such as oilseeds (especially soybeans), meat by-products (such as blood meal and bone meal) and microbial proteins. Complete replacement of FM and fish oil in finfish aquaculture feed has been met with several drawbacks. Particularly for carnivorous fish, vegetable proteins have inappropriate amino-acid balance, poor protein digestibility and anti-nutritional substances. Necessitating research into the inclusion of other highly nutritious supplements such as microalgae and/or meat by-products.

It is, however, important to note that these ingredients do not always meet the expected ecological, nutritional and economical requirements. As a consequence, both finfish and ornamental aquaculture could benefit alternatives that ensure fish health and welfare standards by providing proper feeding stimulants, proper levels of essential amino acids and polyunsaturated fatty acids (PUFAs), high nutrient and energy bioavailability, as well as reduced antinutritional factors. The insect meal instead of fishmeal is becoming more common in the aquaculture sector of many countries. Fishmeal is not eco-friendly as a principal dietary protein source; it is also not costeffective as the price continues to increase. Animal and fishery by-products and plant-derived material are now used as substitutes (FAO, 2014). Plant protein derivatives rarely have a balanced essential amino acid (EAA) profile and often contain antinutritive factors. 
Processed animal protein is considered a valuable alternative as it has a better EAA profile and is more digestible than plant proteins; however, there are restrictions on the use of certain processed animal proteins within the Europe Community, this serves to protect against transmissible spongiform encephalopathies (Regulation 68/2013/EC, 2013) (Bruni, et al., 2018). The increasing attention attracted recently by insects as a sustainable nutrient source for feed is not only in Europe but also around the world. Insects are a good source of EAA, lipids, vitamins and minerals (Henry et al., 2015; van Huis et al., 2013); they grow and reproduce quickly and easily on lowquality organic waste and manure (van Huis et al., 2013); they have a small ecological footprint and high feed conversion efficiency (Makkar et al., 2014), and can reasonably foster a circular bioeconomy (Bruni et al., 2018).

According to Panini et al. weight gain, specific growth rate, feed intake, feed conversion, survival, and protein retention of pacific white shrimp were not affected by replacing fishmeal with mealworm meal. There were no significant differences in protein content between the treatments. But, the moisture content showed a linear decrease with an increase in the fishmeal replacement level while the lipid content increased with MM inclusion level (Panini et al., 2017).

In 2014, about $10 \%$ of world fish production (captured and aquaculture) went into fish meal and fish oil production. Fish meal is made from small wildcaught marine fish that contain a high percentage of bones and oil, and are usually deemed unsuitable for direct human consumption. Fish meal is a high-quality feed ingredient for pigs, poultry, and aquaculture and is used extensively. However, it is becoming increasingly scarce and expensive. Between 1988 and 2010, the poultry sector decreased the use of fish meal from $60 \%$ to $12 \%$ while the aquaculture sector increased its use of fish meal from 10 to $56 \%$ in the same period. Increasing fish meal prices have led to lower inclusion percentages in aquafeed, however, the effect is not evident on fish meal use as it is quickly offset by the rapid growth of the aquaculture sector (van Huis and Oonincx, 2017). This has necessitated the search for alternative sources, for instance, the use of plant material. Plant materials have several drawbacks although they can be partly mediated by chemical and mechanical processing (van Huis and Oonincx, 2017).

However, certain insect species might also serve as alternative protein sources without these drawbacks, in particular, the black soldier fly Hermetia illucens (L.) (Diptera: Stratiomyidae). Studies conducted with Atlantic salmon showed that fish meal can be completely replaced in their diet without adverse effects on net growth of the fish, histology, odour, flavour/taste, and texture (Lock et al., 2015). Similarly, meal made from the black soldier fly is a suitable protein source for a number of other farmed fish species, such as African catfish Clarias gariepinus (Adeniyi and Folorunsho, 2015; Anvo et al., 2016), Channel catfish Ictalurus punctatus, and Blue tilapia Oreochromis aureus (Bondari and Sheppard, 1987).
Another insect species, the Yellow mealworm (Tenebrio molitor L.; Coleoptera: Tenebrionidae), has also been evaluated. Yellow mealworm meal could partially $(35 \%)$ replace fish meal in the diet of European sea bass (Dicentrarchus labrax) without affecting mortality or growth (Gasco et al., 2016). However, replacing $70 \%$ of the fish meal did depress growth. A similar trial conducted with Rainbow trout (Oncorhynchus mykiss) found that weight gain was not affected at higher inclusion levels of mealworm meal, while the protein content increased and lipid contents of fillets decreased, compared to the control (Belforti et al., 2015; van Huis and Oonincx, 2017).

One major problem related to the inclusion of insect meal in aquafeeds is the presence of chitin which is likely to induce a general reduction of the diet digestibility. The effects of the chitin in fish feeds are however yet to be fully understood, as results are controversial. Some previous studies have shown that moderate inclusion of chitin resulted in increased fish immune response and positive microbiota modulation although negative effects have also been reported for example; possible intestinal inflammation and reduced nutrient digestibility and assimilation (VargasAbúndeza et al., 2019). More recent studies, however, show no signs of severe intestinal inflammation by the histological analyses in all the samples analyzed, except for a reduction in intestinal fold length that was exclusively observed in fish fed $50 \%$ and $75 \%$ Hermetia illucens meal substitution diets.

The shortening of intestinal folds has previously been associated to impaired nutrient absorption translating to growth reduction (Moldal et al., 2014); however, in the present study this was not observed and the GR and HSP70 molecular markers involved in stress response, this markers are useful for detecting stress; inflammation, physiological responses, and there was no significant difference among groups, suggesting a general fish welfare. Insect fatty acid composition could be the reason for the absence of intestine inflammation (Vargas-Abúndeza et al., 2019).

Defatted Black soldier fly larvae meal (DBSFLM) has been shown as a promising fish meal (FM) substitute in diets for Turbot, Rainbow trout, Jian carp, Pacific white shrimp and Atlantic salmon. Wang et al. examined DBSFLM as an alternative protein source in Japanese seabass (Lateolabrax japonicus) diets. Five diets were formulated by replacing $0 \%$ (FM), 16\%, $32 \%, 48 \%$ and $64 \%$ fish meal. Results showed that growth performance, somatic indexes, hepatic and intestinal histomorphology, and the intestinal antioxidant and immunity indexes of fish were not affected by dietary treatments. At $48 \%$ and $64 \%$ insect meal inclusion there was higher feed intake, but lower whole body ash content and ash retention, lower serum concentrations of total cholesterol, triacylglycerol, high-density lipoprotein cholesterol and malondialdehyde than those fed FM. Inclusion of insect meal did not alter activities of hepatic trypsin, lipase and amylase, but increased activity of intestinal lipase for fish fed $48 \%$ and $64 \%$ insect meal than those fed FM (Wang et al., 2019). 
Four diets were formulated with 4\% (D4), 8\% (D8), $12 \%$ (D12), and 16\% (D16) Tenebrio molitor protein and compared with a control to investigate the effects of $T$. molitor protein on growth performance, immunological parameters, and resistance against Lactococcus garvieae and Aeromonas hydrophila in Macrobrachium rosenbergii. After 10weeks of the experiment, the study found that weight gain (WG), percentage of weight gain (PWG), daily growth rate (DGR), specific growth rate (SGR), and protein efficiency ratio (PER) of D12 were significantly higher than those of the control, D4, and D8, but not significantly different from those of D16. The condition factor $(\mathrm{K})$, feed conversion ratio (FCR), and survival rate (SR) did not differ significantly among groups. Lipid content decreased and protein content increased in the carcass and muscle of prawns as T. molitor protein contents increased (Feng et al., 2019).

Insect meal (IM) was produced from Black soldier fly (BSF, Hermetia illucens) larvae. Seawater Atlantic salmon were fed three different diets for 8 weeks; a control diet (IM0, protein from fishmeal and plantbased ingredients $(25: 75)$ and lipid from fish oil and vegetable oil (33:66); and two insect-meal containing diets, IM66 and IM100, where 66 and $100 \%$ of the fishmeal protein were replaced with IM, respectively. There were no significant effects of IM inclusion on final weight or any of the growth or feed intake parameters (specific growth rate (SGR), food conversion ratio (FCR), feed intake (FI), hepatic somatic index (HSI) and visceral somatic index (VSI) (Stenberg et al., 2019).

Partly defatted Hermetia meal (HM) could replace soy protein up to $50 \%$ in Nile Tilapia as above this inclusion level there could be impairment in growth (Dietz and Liebert, 2018).

European sea bass, Dicentrarchus labrax, fed with Tenebrio molitor larval meal for 6 weeks showed significant anti-inflammatory responses (ceruloplasmin, myeloperoxidase and nitric oxide). Incorporation of insect larvae into the fish diet is a relatively new research area and to our knowledge, so far there has only been a few studies on the effect of insect meal on the immune system and antioxidant enzymes of the fish: Black carp (Mylopharyngodon piceus) fed with low doses (2.5\%) of maggot (Musca domestica) for 60 days showed increased serum lysozyme, serum complement and liver SOD and CAT activities and reduced liver MDA suggesting an increased antibacterial activity and an antioxidant activity of the insect meal at low dietary dose (Ming, et al., 2013). The insect meal also protected these fish against a bacterial challenge with Aeromonas hydrophila (Ming et al., 2013). A similar study in Red seabream (Pagrus major) showed that the introduction of low doses 0.75 and $7.5 \%$ of Housefly (Musca domestica) pupae in the diet of red sea bream for 10 days showed a significant increase of the phagocytic activity of peritoneal macrophages (Ido et al., 2015).

Interestingly, $5 \%$ of dietary housefly pupae for 2 months did protect (100\% survival) the fish against the bacterial pathogen Edwardsiella tarda while all control fish died 12 days after the bacterial challenge (Ido et al., 2015). The protective effect of dietary insects was suggested to be either direct through the secretion of antimicrobial peptides by the insect, indirect through the stimulation of the fish immune system by chitin (Esteban et al., 2001; Esteban et al., 2000; Lee et al., 2008) or by other insect components (Ido et al., 2015).

The first hypothesis involving the secretion of antimicrobial peptides by the insects seemed however unlikely as dead insects do not secrete any AMPs. The indirect effect through the immunostimulation of the fish was, therefore, more likely (Henry et al, 2018).

\section{OPINION}

The use of insect as food and feed has started long before now in Africa, Asia and South America where edible insects are part of their diets. These insects have been shown to be highly nutritious, their protein content and amino acid profile comparable to soymeal and fishmeal. The benefits of insects as feedstuff does not end only with the aspect of nutrition, its production also has less environmental footprint. In fact, it can be a way of converting agricultural products that go to waste to protein mass useful for animal production. With the rising questions and concern on the sustainability, economic and environmental impact of using fishmeal and soymeal which could have been used to address rising world hunger in animal production. There is a need for an alternative protein source, especially in the feed industry. With the many upsides of using insect protein as an alternative protein source, there has been an intensification of research on insect as a protein source in Europe. Approximately $71 \%$ of the articles reviewed for this article are from Europe both in the food and feed industry. Despite the increase, there is still much work to be done and of particular interest is the use of insect as an alternative protein source in aquaculture. The aquaculture industry is rapidly growing and this growth is expected to continue but capture fish landing which is the source fishmeal is not growing but rather declining. A welcome development for aquaculture is the (2017/893-24/07/2017) that has authorized the use of 7 insects in aquafeeds.

However, there is a need for intensification of research on the use of insects in feed because of;

- Dynamic nutritional composition of insect-based on their species, stage of life cycle, feed as well as processing method

- Different effect on aquatic species from previous research based on the inclusion level and species of insect.

Based on the points stated above there is need to research the feasibility of using insect protein on each commercially viable species to know the appropriate insect species and right inclusion level.

So much of past research on insects has focused on investigating the growth effect on animal, a few on their immunomodulatory effects but next to nothing has been done on the economic implication. Roffeis et al. in 2018 did a cost assessment of insect-based feed 
production in west Africa and the study revealed that insect-based feed had the potential of substituting imported fishmeal based on the breakeven sales price (Roffeis et al., 2018).

Another important aspect that not gotten a lot of attention with regards to research is the safety of insect meant for feed production. Some fungi bacteria and viruses have been found in insects, for example, densovirus in A domesticus and Gryllodus species, cricket paralysis virus in crickets, fungi (fusarium, cladosporium species) However the available information from research shows that most viruses that are taxonomically related to insect are unable to replicate in the insect and as such pose, no health concern, the burden related to virus of insect are carried by the insect farm. The processing of insect plays an important role in mitigating some of these safety concerns. However, there is need for researching the arboviruses as they can cause human disease and can also replicate in their vector. Food and feed derived from insects could also contain chemical contaminants which occur as a result of the presence of such contaminant in the environment and/or the substrate. These chemicals include heavy metals, veterinary drug residues, organohalogen compounds, and pesticide residues. The chemicals of concern vary, accordingly to the type of feeding substrate. For instance, insects reared on agricultural waste may be exposed to plant protection products and mycotoxins, while insects reared on manure may be exposed predominantly to veterinary drug residues (van der Fels-Klerx et al., 2018).

\section{REFERENCES}

Adeniyi, O.-Folorunsho, C. (2015): Performance of Clarias gariepinus (Burchell, 1822) fed dietary levels of black soldier fly, Hermetia illucens (Linnaeus, 1758) prepupae meal as a protein supplement. Int J Res Fish Aquat, 5, 89-93.

Aiking, H. (2011): Future protein supply. Trends in Food Science \& Technology, 22(2-3), 112-120.

Alexander, P.-Rounsevell, M. D.-Dislich, C.-Dodson, J. R.Engström, K.-Moran, D. (2015): Drivers for global agricultural land use change: The nexus of diet, population, yield and bioenergy. Global Environmental Change, 35, 138-147.

Alexandera, P.-Brown, C.-Arneth, A.-Dias, C.-Finnigan, J.-Moran, D.-Rounsevell, M. D. (2017): Could consumption of insects, cultured meat or imitation meat reduce global agricultural land use? Global Food Security, 15, 22-32.

Allegretti, G.-Talamini, E.-Schmidt, V.-Bogorni, P. C.-Ortega, E. (2018): Insect as feed: An emergy assessment of insect meal as a sustainable protein source for the Brazilian poultry industry. Journal of Cleaner Production, 171, 403-412.

Anvo, M.-Toguyéni, A.-Otchoumou, A.-Zoungrana-Kaboré, C. Y.Kouamelan, E. (2016): Evaluation of Cirina butyrospermi caterpillar's meal as an alternative protein source in Clarias gariepinus (Burchell, 1822) larvae feeding. Int J Fish Aquat Stud, 4(6), 88-94.

Barroso, F. G.-Haro, C. D.-Sánchez-Muros, M.-J.-Venegas, E.Martínez-Sánchez, A.-Pérez-Bañón, C. (2014): The potential of various insect species for use as food for fish. Aquaculture 422 423 (2014) 193-201, 422-423, 193-201.

Belforti, M.-Gai, F.-Lussiana, C.-Renna, M.-Malfatto, V.-Rotolo, L.-De Marco, M.- Dannou, S.-Schivone, A.-Zoccarato, I.Gasco, L. (2015): Tenebrio molitor meal in rainbow trout (Oncorhynchus mykiss) diets: effects on animal performance, nutrient digestibility and chemical composition of fillets. Ital $\mathbf{J}$ Anim Sci., 14, 4170.

Belluco, S.-Losasso, C.-Maggioletti, M.-Alonzi, C. C.-Paoletti, M. G.-Ricci, A. (2013): Edible Insects in a Food Safety and Nutritional Perspective: A Critical Review. Comprehensive Reviews in Food Science and Food Safety, 12, 296-313.

Blásquez, J. R.-E.-Moreno, J. M.-Camacho, V. H. (2012): Could Grasshoppers Be a Nutritive Meal? Food and Nutrition Sciences, , 3, 164-175.

Bondari, K.-Sheppard, D. (1987): Soldier fly, Hermetia illucens L., larvae as feed for channel catfish, Ictalurus punctatus
(Rafinesque), and blue tilapia, Oreochromis aureus (Steindachner). Aquac FishManag, 18, 209-220.

Bosch, G.-Zhang, S.-Oonincx, D.-Hendriks, W. H. (2014): Protein quality of insects as potential ingredients for dog and cat foods. Journal of Nutritional Science, 3, e29.

Bovera, F.-Loponte, R.-Marono, S.-Piccolo, G.-Parisi, G.-Iaconisi, V.-Nizza, A. (2016): Use of Tenebrio molitor larvae meal as protein source in broiler diet: Effect on growth performance, nutrient digestibility, and carcass and meat traits. Journal of Animal Science, 94(2), 639-647.

Bruni, L.-Pastorelli, R.-Viti, C.-Gasco, L.-Parisi, G. (2018): Characterisation of the intestinal microbial communities of rainbow trout (Oncorhynchus mykiss) fed with Hermetia illucens (black soldier fly) partially defatted larva meal as partial dietary protein source. Aquaculture, 487, 56-63.

Bukkens, S. (2005): Insects in the Human Diet: Nutritional Aspects. In M. Paoletti, Ecological implication of minilivestock; Role of rodents, frogs, snail and insect in sustainable development. New Hampshire: Science publisher. pp. 545-577.

Čičková, H.-Pastor, B.-Kozánek, M.-Martínez-Sánchez, A.-Rojo, S.-Takáč, P. (2012): Biodegradation of Pig Manure by the Housefly, Musca domestica: A Viable Ecological Strategy for Pig Manure Management. PLoS ONE, 7(3), e32798.

de Castro, R. J.-Ohara, A.-Aguilara, J. G.-Domingues, M. A. (2018): Nutritional, functional and biological properties of insect proteins: Processes for obtaining, consumption and future challenges. Trends in Food Science \& Technology, 76, 82-89.

Dietz, C.-Liebert, F. (2018): Does graded substitution of soy protein concentrate by an insect meal respond on growth and $\mathrm{N}$ utilization in Nile tilapia (Oreochromis niloticus)? Aquaculture Reports, 12, 43-48.

Elzerman, J. E.-Hoek, A. C.-Boekel, M. A.-Luning, P. A. (2011): Consumer acceptance and appropriateness of meat substitutes in a meal context. Food Quality and Preference, 22(3), 233-240.

Esteban, M.-Cuesta, A.-Ortuño, J.-Meseguer, J. (2001): Immunomodulatory effects of dietary intake of chitin on gilthead seabream (Sparus aurata L.) innate immune system. Fish \& Shellfish Immunology, 11(4), 303-315.

Esteban, M.-Mulero, V.-Cuesta, A.-Ortuño, J.-Meseguer, J. (2000): Effects of injecting chitin particles on the innate immune response of gilthead seabream (Sparus aurata L.). Fish \& Shellfish Immunology, 10(6), 543-554. 
Fasolin, L.-Pereira, R.-Pinheiro, A.--Martins, J.-Andrade, C.Ramos, O.-Vicente, A. (2019): Emergent food proteins Towards sustainability, health and innovation. Food Research International, 125, 1-16.

Feng, P.-He, J.-Lv, M.-Huang, G.-Chen, X.-Yang, Q.-Ma, H. (2019): Effect of dietary Tenebrio molitor protein on growth performance and immunological parameters in Macrobrachium rosenbergii. Aquaculture, 511, 1-9.

Finke, M. D.-Oonincx, D. (2014): Chapter 17 - Insects as Food for Insectivores. In: Finke, M. D.-Oonincx, D.--Morales-Ramos, J. A.-Rojas, M. G.-Shapiro-Ilan, D. I. (Eds.), Mass Production of Beneficial Organisms. San Diego: Academic press. pp. 583-616.

Gasco, L.-Henry, M.-Piccolo, G.-Marono, S.-Gai, F.-Renna, M.Lussiana, C.-Antonopoulou, F.-Mola, P.-Chatzifotis, S. (2016): Tenebrio molitor meal in diets for European sea bass (Dicentrarchus labrax L.) juveniles: growth performance, whole body composition and in vivo apparent digestibility. Anim Feed Sci Technol. Animal Feed Science Technology, 220, 34-45.

Gold, M.-Tomberlin, J. K.-Diener, S.-Zurbrügg, C.-Mathys, A. (2018): Decomposition of biowaste macronutrients, microbes, and chemicals in black soldier fly larval treatment: A review. Waste Management, 82, 302-318.

Hall, F. G.-Jones, O. G.-O'Haire, M. E.-Liceaga, A. M. (2017): Functional properties of tropical banded cricket (Gryllodes sigillatus) protein hydrolysates. Food Chemistry, 224, 414-422.

Henry, M.-Gasco, L.-Chatzifotis, S.-Piccolo, G. (2018): Does dietary insect meal affect the fish immune system? The case of mealworm, Tenebrio molitor on European sea bass, Dicentrarchus labrax. Developmental and Comparative Immunology, 81, 204-209.

Henry, M.-Gasco, L.-Piccolo, G.-Fountoulaki, E. (2015): Review on the use of insects in the diet of farmed fish: Past and future. Animal Feed Science and Technology, 203, 1-22.

Herrero, M.-Henderson, B.-Havlík, P.-Thornton, P. K.-Conant, R. T.-Smith, P.-Stehfest, E. (2016): Greenhouse gas mitigation potentials in the livestock sector. Nature Climate Change, 6(5), 1758-6798.

Houghton, R. A.-House, J. I.-Pongratz, J.-Werf, G. R.-DeFries, R. S.-Hansen, M. C.-Ramankutty, N. (2012): Carbon emissions from land use and land-cover change. Biogeosciences, 9, 51255142 .

House, J. (2016): Consumer acceptance of insect-based foods in the Netherlands: Academic and commercial implications. Appetite, $107,47-58$.

House, J. (2018): Insect as food in the Netherlands: Production networks and the geographies of edibility. Geoforum, 94, 82-93.

Ido, A.-Iwai, T.-Ito, K.-Ohta, T.-Mizushige, T.-Kishida, T.-Miura, T. (2015): Dietary effects of housefly (Musca domestica) (Diptera: Muscidae) pupae on the growth performance and the resistance against bacterial pathogen in red sea bream (Pagrus major) (Perciformes: Sparidae). Applied Entomology and Zoology, 50(2), 213-221.

Jin, X.-Heo, P.-Hong, J.-Kim, N.-Kim, Y. (2016): Supplementation of mealworm (Tenebrio molitor larva) on growth performance, nutrient digestibility and blood profiles in weaning pigs. Asian Australas. J. Anim., 29, 979-986.

Kierończyk, B.-Rawski, M.-Józefiakc, A.-Mazurkiewicz, J.Świątkiewicz, S.-Siweke, M.-Józefiak, D. (2018): Effects of replacing soybean oil with selected insect fats on broilers. animal feed science technology, 240, 170-183.

Kouřimská, L.-Adámková, A. (2016): Nutritional and sensory quality of edible insects. NFS Journal, 4, 22-26.
Kroeckel, S.-Harjes, A. G.-Roth, I.-Katz, H.-Wuertz, S.-Susenbeth, A.-Schulz, C. (2012): When a turbot catches a fly: Evaluation of a pre-pupae meal of the Black Soldier Fly (Hermetia illucens) as fish meal substitute - Growth performance and chitin degradation in juvenile turbot (Psetta maxima). Aquaculture, 364-365, 345-352.

Lammers, P.-Ullmann, L. M.-Fiebelkorn, F. (2019): Acceptance of insects as food in Germany: Is it about sensation seeking, sustainability consciousness, or food disgust? Food Quality and Preference, 77, 78-88.

Lee, C.-Da Silva, C.-Lee, J.-Y.-Hartl, D.-Elias, J. (2008): Chitin regulation of immune responses: an old molecule with new roles. Current Opinion in Immunology, 20(8), 684-689.

Li, S.-Ji, H.-Zhang, B.-Tian, J.-Zhou, J.-Yu, H. (2016): Influence of black soldier fly (Hermetia illucens) larvae oil on growth performance, body composition, tissue fatty acid composition and lipid deposition in juvenile Jian carp (Cyprinus carpio var. Jian). Aquaculture, 465, 43-52.

Loponte, R.-Nizza, S.-Bovera, F.-De Riu, N.-Fliegerova, K.Lombardi, P.-Vassalotti, G.-Mastellone, V.-Nizza, A.Moniello, G. (2017): Growth performance, blood profiles and carcass traits of Barbary partridge (Alectoris barbara) fed two different insect larvae meals (Tenebrio molitor and Hermetia illucens). Research in Veterinary Science, 115, 183-188.

Machado, C. D.-Thys, R. C. (2019): Cricket powder (Gryllus assimilis) as a new alternative protein source for gluten-free breads. Innovative Food Science and Emerging Technologies, $56,1-7$.

Makkar, H. P.-Tran, G.-Heuzé, V.-Ankers, P. (2014): State-of-theart on use of insects as animal feed. Animal Feed Science and Technology, 197, 1-33.

Mancini, S.-Moruzzo, R.-Riccioli, F.-Paci, G. (2019): European consumers' readiness to adopt insects as food. A review. Food Research International, 122, 661-678.

Maurer, V.-Holinger, M.-Amsler, Z.-Früh, B.-Wohlfahrt, J., Stamer, A.-Leiber, F. (2016): Replacement of soybean cake by Hermetia illucens meal in diets for layers. Journal of Insects as Food and Feed, 2(2), 83-90.

Mba, A. R.-Kansci, G.-Viau, M., Rougerie, R.-Genot, C. (2019): Edible caterpillars of Imbrasia truncata and Imbrasia epimethea contain lipids and proteins of high potential for nutrition. Journal of Food Composition and Analysis, 79, 70-79.

Megido, R. C.-Gierts, C.-Blecker, C.-Brostaux, Y.-Haubruge, É.Alabi, T.-Francis, F. (2016): Consumer acceptance of insectbased alternative meat products in Western countries. Food Quality and Preference, 52, 237-243.

Miech, P.-Berggren, A.--Lindberg, J.-Chhay, T.-Khieu, B.-Jansson, A. (2016): Growth and survival of reared Cambodian field crickets (Teleogryllus testaceus) fed weeds, agricultural and food industry by-products. Journal of Insects as Food and Feed, 2(4), 285-292.

Ming, J.-Ye, J.-Zhang, Y.-Yang, X.-Wu, C.-Shao, X.-Liu, P. (2013): he influence of maggot meal and 1-carnitine on growth, immunity, antioxidant indices and disease resistance of black carp (Mylopharyngodon piceus). Journal of the Chinese Cereals and Oils Association, 28(2), 80-86.

Moldal, T.-Løkka, G.-Wiik-Nielsen, J.,-Austbø, L.-Torstensen, B. E.-Rosenlund, G.-Dale, O. B.-Kaldusdal, M.-Koppang, E. O. (2014): Substitution of dietary fish oil with plant oils is associated with shortened mid intestinal folds in Atlantic salmon. BMC Veterinary Research, 10(1), 1746-6148. 
Oonincx, D. G.-Boer, I. J. (2012): Environmental Impact of the Production of Mealworms as a Protein Source for Humans - A Life Cycle Assessment. PLOS ONE, 7(12), 1-5.

Oonincx, D.-Itterbeeck, J. V.-Heetkamp, M. J. W.-Brand, H. V.Loon, J. V.-Huis, A. V. (2010). An exploration on greenhouse gas and ammonia production by insect species suitable for animal or human consumption. PLoS One , 5(12), 1-7.

Panini, R. L.-Freitas, L. E.-Guimarães, A. M.-Rios, C.-Silva, M. F.Vieira, F. N.-Fracalossi, D. M.-Samuels, R. I.-Prudencio, E.Silva, C.-Amboni, R. D. (2017): Potential use of mealworms as an alternative protein source for Pacific white shrimp: Digestibility and performance. Aquaculture, 473, 115-120.

Pastor, B.-Velasquez, Y.-Gobbi, P.-Rojo, S. (2015): Conversion of organic wastes into fly larval biomass: bottlenecks and challenges. Journal of Insects as Food and Feed, 1(3), 179-193.

Patel, S. H. A.-Rauf, A. (2019): Edible insects as innovative foods: Nutritional and functional assessments. Trends in Food Science \& Technology 86 (2019) 352-359, 86, 352-359.

Pimentel, D.-Pimentel, M. (2003): Sustainability of meat-based and plant-based diets and the environment. The American Journal of Clinical Nutrition, 78(3), 660-663.

Ravi, H. K.-Vian, M. A.-Tao, Y.-Degrou, A.-Costil, J.-Trespeuch, C.-Chemat, F. (2019): Alternative solvents for lipid extraction and their effect on protein quality in black soldier fly (Hermetia illucens) larvae. Journal of Cleaner Production, 238, 1-13.

Reynolds, J. C.-Buckley, D. J.-Weinstein, P.-Boland, J. (2014): Are the Dietary Guidelines for Meat, Fat, Fruit and Vegetable Consumption Appropriate for Environmental Sustainability? A Review of the Literature. Nutrients, 6(6), 2251-2265.

Roffeis, M.-Wakefield, M. E.-Almeida, J.-Valada, T. R.-Devic, E.Kone, N.-Kenis, M.-Nacambo, S.- Fitches, E. C.-Koko, G.Mathijs, E.-Achten, W.-Muys, B. (2018): Life cycle cost assessment of insect based feed production in West Africa. Journal of Cleaner Production, 199, 792-806.

Sánchez-Muros, M.-J.-Barroso, F. G.-Manzano-Agugliaro, F. (2014): Insect meal as renewable source of food for animal feeding: a review. Journal of Cleaner Production, 65, 16-27.

Shah, R. M.-Azhar, F.-Shad, S. A.-Walker, W. B.-Azeem, M.Binyameen, M. (2016): Effects of different animal manures on attraction and reproductive behaviors of common house fly, Musca domestica L. Parasitology Research, 115(9), 3585-3598.

Shelomi, M. (2015): Why we still don't eat insects: Assessing entomophagy promotion through a diffusion of innovations framework,. Trends in Food Science \& Technology, 45(2), 311318.

Steinfeld, H.-Gerber, P.-Wassenaar, T. D.-Castel, V.--Rosales, M.M., M. R.-Haan, C. D. (2006): Livestock's Long Shadow: Environmental Issues and Options. Rome Italy: Food and Agriculture Organization of the United Nations,
Stenberg, O. K.-Holen, E.-Piemontese, L.-Liland, N. S.-Lock, E.J.-Belghit, M. E. ( 2019): Effect of dietary replacement of fish meal with insect meal on in vitro bacterial and viral induced gene response in Atlantic salmon (Salmo salar) head kidney leukocytes. Fish and Shellfish Immunology, 91, 223-232.

Testa, M.-Stillo, M.-Maffei, G.-Andriolo, V.-Gardois, P.-Zotti, C. M. (2017): Ugly but tasty: A systematic review of possible human and animal health risks related to entomophagy. Critical Reviews in Food Science and Nutrition, 57(17), 3747-3759.

Tzompa-Sosa, D. A.-Yi, L.-Valenberg, H. J.-Boekel, M. A.Lakemond, C. M. (2014): Insect lipid profile: aqueous versus organic solvent-based extraction methods. Food Research International, 62, 1087-1094.

van Broekhoven, S.-Oonincx, D. G.-Huis, A. V.-Loon, J. J. (2015): Growth performance and feed conversion efficiency of three edible mealworm species (Coleoptera: Tenebrionidae) on diets composed of organic by-products. Journal of Insect Physiology, $73,1-10$

van der Fels-Klerx, H. J.-Camenzuli, L.-Belluco, S.-Meijer, N.Ricci, A. (2018): Food Safety Issues Related to Uses of Insects for Feeds and Foods. Comprehensive Reviews in Food Science and Food Safety, 17(5), 1172-1183.

van Huis, A. (2013): Potential of Insects as Food and Feed in Assuring Food Security. Annual Review of Entomology, 58, 563-583.

van Huis, A.-Oonincx, D. G. (2017): The environmental sustainability of insects as food and feed. A review. Agronomy for Sustainable Development, 37(5), 43.

van Huis, A.-Itterbeeck, J. V.-Klunder, H.-Mertens, E.-Halloran, A.-Muir, G.-Vantomme, P. (2013): Edible insects Future prospects for food and feed security. food and agriculture organization of the United Nations. Rome: FAO.

Vargas-Abúndeza, A. J.-Randazzoa, B.-Foddai, M.-Sanchini, L.Truzzi, C.-Giorgini, E.-Gasco, L.-Olivotto, I. (2019): Insect meal based diets for clownfish: Biometric, histological, spectroscopic, biochemical and molecular implications. Aquaculture , 498, 1-11.

Wang, G.-Penga, K.-Hu, J.-Yi, C.-Chen, X.-Wu, H.-Huang, Y. (2019): Evaluation of defatted black soldier fly (Hermetia illucens $\mathrm{L}$.) larvae meal as an alternative protein ingredient for juvenile Japanese seabass (Lateolabrax japonicus) diets. Aquaculture (507), 144-154.

Zielińska, E.-Karaś, M.-Baraniak, B. (2018): Comparison of functional properties of edible insects and protein preparations thereof. LWT - Food Science and Technology, 91, 168-174. 